\title{
SOBRE LA NECESARIA DIFUSIÓN CIENTÍFICA A TRAVÉS DE LOS MEDIOS DE COMUNICACIÓN SOCIAL
}

\author{
Norma Hernández Escobar \\ Universidad Evangélica de El Salvador \\ Norma.hernandez@uees.edu.sv
}

Con la llegada del internet, la información circula cada día de forma más veloz y está disponible para las nuevas generaciones de estudiantes -desde la primaria hasta la universitaria- y para todas las personas que tienen acceso a este instrumento de comunicación y difusión.

Por otra parte, el conocimiento es un derecho del individuo y parte inherente de la cultura de las sociedades. El conocimiento contribuye a que las personas sean críticas de su entorno inmediato y futuro; la cultura implica también el conjunto de saberes, creencias y pautas de conducta. En ese sentido, la ciencia debe concebirse como parte esencial de la cultura. Por ello resulta insostenible aquella idea o paradigma que postula que el conocimiento científico debe ser dominado exclusivamente por especialistas.

De hecho, los avances científicos plantean y abren nuevos horizontes de debate, y esto no puede quedar al margen de la participación ciudadana. La ciencia opera como un sistema cultural y se integra o aviva los conflictos sociales; en otras palabras, la presencia de temas científicos en los medios de comunicación es fundamental para la sinergia entre la academia y la cotidianidad social.

Por tanto, es necesario que los ciudadanos conozcan más de cerca a los actores que generan la ciencia, mejorar sus posibilidades de acceso y fortalecer la comunicación entre todos los agentes implicados. En realidad, buena parte de las personas está pendiente de la nueva información que se genera, y toman muchas decisiones a partir de la información que le brindan los comunicadores, por lo que la información se convierte en tema de vital interés para ambas partes, el medio y sus lectores, en todas sus formas de recepción.

Pero también es necesario conocer a los autores que generan la ciencia y mejorar la comunicación entre todos. Por ello es urgente realizar importantes esfuerzos de difusión científica que fomenten en el ciudadano el deseo de ser parte de los debates serios, emitiendo su opinión como parte del tejido social del desarrollo.

Ante esta nueva realidad, se han acuñado nuevas palabras y términos que han expandido el conocimiento sobre problemas científicos tratados mundialmente que requieren de un mínimo de entendimiento sobre sus causas y efectos, pero que inciden en el desarrollo humano. Y es en este contexto, que el papel que juegan los Medios de Comunicación Social (MCS) en la dinámica de informar oportuna y objetivamente se vuelve más necesaria que 
nunca, y no debe haber tiempo y espacio que la limiten. Es aquí donde se podría hablar de la necesidad de promover una cultura de la ciencia y un periodismo científico.

Entendemos entonces por periodismo científico a aquel que traslada a sus lectores temas de investigación científica y tecnológica que producen los centros de investigación, con el objetivo de crear un clima de saberes y construcción de una ciencia pública que abone a la integración del individuo en la civilización tecnológica y una sociedad del conocimientode temas especializados.

Por supuesto que surge la duda sobre si la ciencia debe ser parte de la cultura de los pueblos, o si el periodismo científico debe o puede ser el puente entre la investigación y la cotidianidad de la sociedad que no está vinculada con la comunidad científica-académica; o sobre cómo interesar a los dueños y editores de los MCS para que se animen a dar cada vez más cobertura a este tipo de información.

Mientras se continúa el debate, y volviendo la mirada a nuestra realidad, mantendremos la necesidad de que los resultados de las investigaciones científicas se pueden y deben convertir en noticia, y que esta información sea retomada por la población, para así abonar a la construcción de una sociedad más informada en temas académicos. En ese sentido, nos preguntamos si para los salvadoreños la investigación científica es un tema recurrente en la información que reciben a través de los diferentes medios de comunicación social nacionales; por lo que nos surge la pregunta ¿se interesan los MCS salvadoreños por publicar temas o noticias amparadas en fuentes científicas?

Es bastante claro que los medios de comunicación son los que deciden la agenda diaria, y lo que quiere la línea editorial que la población conozca. En otras palabras, son los MCS los que hacen la noticia y a veces hasta la realidad; pero dejan fuera de la agenda y de la realidad muchos temas importantes para el desarrollo intelectual o educativo de los salvadoreños, pues muy rara vez dan cobertura a actividades académicas promovidas por las universidades o los centros de investigación. A pesar de lo anterior, se debe reconocer también que los científicos no están pensando en que los resultados o avances de sus investigaciones se puedan socializar, en este caso la sociedad en general, no solo con el mundo académico o sus pares especializados, sino con otros destinatarios. Ambos errores deben ser corregidos.

Por todo lo anterior, el periodismo científico en El Salvador debe convertirse en una especialidad de nuestro tiempo, que desarrolle sus propias perspectivas profesionales y proyecciones hacia el futuro, por la sencilla razón de que cada vez más todas las sociedades -incluyendo la salvadoreña- se ven influenciadas por la ciencia y la tecnología. De tal manera, que si el periodismo es el reflejo de lo que ocurre diariamente en la vida pública, el periodismo científico debe hacer un esfuerzo por lograr la confluencia de la cultura, la ciencia, la educación, la investigación y la tecnología.

Hay que reconocer que un elemento importante que limita a este tipo de difusión informativa es la resistencia por parte de los MCS a publicar temas áridos -como los pueden catalogar los editores en jefe-, argumentando falta de interés de los receptores. No se tiene la conciencia de que la ciencia opera como un sistema cultural y se integra a los conflictos sociales, por lo que hay que aprender a entender cómo funciona. 
Parte del científico también debe contribuir a que esta información sea más simple para la comprensión de los términos técnicos y no confundir a los lectores que no son de su especialidad. Aquí es donde el comunicador debe tener la capacidad de comprender la información científica para poder trasladarla a un receptor de diferentes niveles escolaridad. Debe hacerse este esfuerzo, pese a las limitaciones de espacios e interés o desinterés por parte de los editores y directores; se debe hacer un esfuerzo por publicar un artículo proveniente de fuentes académicas de manera clara y accesible, que revele al receptor la importancia de los resultados de una investigación reseñada.

En definitiva, se busca que los investigadores, periodistas y receptores entren a un proceso de formación e identificación del otro, de los eslabones de intereses comunes, y de esa manera ser puente efectivo por donde circule la información científica a través de los espacios que otorguen los MCS, y retroalimentarse mutuamente.

Es pues necesario promover proyectos de difusión que permitan relacionar a los generadores de nuevos datos científicos con los comunicadores y fomentar en el ciudadano el deseo y la necesidad de ser parte de los debates científicos-academicos, que comprenda que tales debates sí están relacionados con su cotidianidad; todo ello será de mucho beneficio para la construcción de una sociedad que exija el derecho a estar informados. Sin duda, los resultados redundarán en el desarrollo de una cultura del conocimiento en El Salvador. 